\title{
Preparedness and Mitigation Measures for Oil and Gas Pipeline Vandalization in the Niger Delta Region of Nigeria
}

\author{
V. O. Emelu \\ Department of Geography and Environmental Management \\ Faculty of Social Sciences, University of Port Harcourt, Nigeria \\ O. S. Eludoyin \\ Department of Geography and Environmental Management \\ Faculty of Social Sciences, University of Port Harcourt, Nigeria

\section{U. Oyegun} \\ Department of Geography and Environmental Management \\ Faculty of Social Sciences, University of Port Harcourt, Nigeria
}

Received: August 7, $2021 \quad$ Accepted: August 24, $2021 \quad$ Published: September 4, 2021

doi:10.5296/emsd.v10i4.18982ＵRL: https://doi.org/10.5296/emsd.v10i4.18982

\begin{abstract}
Owing to poor preparedness and mitigation measures for oil and gas pipeline vandalization in the Niger Delta Region of Nigeria, there have been series of spills that have now reached life threatening levels. This study set out to investigate factors that affect preparedness and mitigation measures for crude oil pipeline vandalism in the study area. The thrust of the study was to unravel the spatial variation in the preparedness and mitigation measures for crude oil pipeline in the region. The study used the survey research method and primary data was sort using questionnaire. The target population were heads of household and workers of multinational companies working in the area. Analysis of variance was used for hypotheses testing at the 0.05 level of significance. The study revealed that the companies' preparedness options were, use of hazard, risk and vulnerability assessment (76\%). Both the community (42\%) and companies (76\%) respondents averred that the preparedness measure adopted in
\end{abstract}


the area were less effective for combating the menace of pipeline vandalism. The mitigation practices against pipeline vandalization adopted included awareness creation, promoting community participation, community policing, community-based pipeline surveillance, community by laws, right of way, punishment for offenders, and excommunication. Majority of the respondent whether community respondents $(48 \%)$ or companies respondents $(84 \%)$ suggested that, the adopted mitigation measures were not effective. The ANOVA model was significant at $\mathrm{p}<0.05(\mathrm{~F}, 14 \mathrm{sig} 0.000)$ meaning that there is statistical significant variation in the level of preparedness for oil and gas pipeline vandalization in the study area. Similarly, the ANOVA model that measured the spatial variation in mitigation measures showed that the model is significant at $\mathrm{p}<0.05(\mathrm{~F}, 16.83$, sig 0.000), meaning there is statistical significant spatial variation in the level of disaster mitigation for oil and gas pipeline vandalization in the study area. The study recommends improvement in surveillance technology, creation of awareness of the dangers of pipeline vandalism to the locals, amongst others.

Keywords: Vandalism, Preparedness, Environmental-degradation, Niger-Delta

\section{Introduction}

The Niger delta region is the main area where oil is produced in Nigeria and a large proportion of the area are wet lands and represents the largest in sub-Saharan Africa (Achumba, Ighomereho, \& Akpan-Robaro, 2013; Adekola, Fischbacher-Smith, Fischbacher-Smith, \& Adekola, 2016). Data shows that around 40b barrels of crude oil reserves and a large amount of gas deposits (Adekola \& Igwe, 2014). The oil sector account for over $90 \%$ of foreign exchange earnings for Nigeria and the bulk of it comes from the Niger delta region (Adishi \& Hunga, 2017). However, the area is also the most polluted in Nigeria, and this is due to oil pipeline vandalism and poor response to crude oil spill disasters over the years (Ahmadu \& Egbodion, 2013; Aigberua, 2017; Ameh, 2013). In the opinion of Atubi, (2015) several factors account for the degradation of the area, which include; gas flaring, industrial pollution, oil spillage, deforestation, coastal flooding (Dalby, 2014). Efforts of government to curb the menace of environmental degradation has met with corruption, fraud and dissatisfaction in the region (Daniel, 2016).

Over the years, crude oil spillage through pipeline vandalism is considered one of the major problems of the region (Okoli \& Orinya, 2013). Rising cases of pipeline vandalism by militant groups have significantly affected sources of revenues of government and oil companies operating in the region (Okoli \& Azom, 2017). There has been diverse opinion regarding the proliferation of militant groups in the area, where as some researchers claim that the militants started to destroy crude oil pipeline to show their anger towards government, for neglecting the area and allowing hunger and diseases to pervade the area (Okon, 2014), others claim that, the militants are mere greedy persons looking for an excuse to make quick wealth (Okonkwo, Kumar, \& Tylor, 2015; Salau, 2016). Whichever way we chose to look at it, government presence in the area is minimal on one hand, and on the other hand, some of the locals are greedy and they want to make quick money (Wizor \& Wali, 2020). The consequence of this is that the pipelines are continuously vandalised at the expense of the environment and sustainable national development. 


\section{Macrothink}

The rate of pipeline vandalization in the study today is alarming and points to the fact that the preparedness level of the oil companies and government to protect the oil pipelines is weak (Sanusi, Onovo, \& Isa, 2016). There continues to be sales of locally refined products in the area, which are by products of stolen crude oil. The mitigation mechanisms in the area are also very weak, so that the environmental consequence of crude oil pipeline vandalism in the area is so costly for humans and the environment. This study therefore investigates the spatial variation in preparedness and mitigation measures for oil and gas pipeline vandalization in the Niger Delta Region.

\section{Materials and Methods}

This study was carried out in the Niger Delta region, which spreads from Aboh $\left(5^{\circ} 33^{\prime} 49^{\prime \prime} \mathrm{N}\right.$ \& 6 $\left.6^{\circ} 31^{\prime} 38^{\prime \prime} \mathrm{E}\right)$ in the North to palm point $\left(4^{\circ} 16^{\prime} 22^{\prime \prime} \mathrm{N} \& 6^{\circ} 05^{\prime} 27^{\prime \prime} \mathrm{E}\right)$ in the South. The East-West limit is between Benin River estuary $\left(5^{\circ} 44^{\prime} 11^{\prime \prime} \mathrm{N} \& 5^{\circ} 3^{\prime} 49^{\prime \prime} \mathrm{E}\right)$ in the West and Imo River estuary $\left(4^{\circ} 27^{\prime} 16^{\prime \prime} \mathrm{N} \& 7^{\circ} 35^{\prime} 27^{\prime \prime}\right.$ E) (see Figure 1) extending towards Guinea gulf of West Africa (Shittu, 2014).

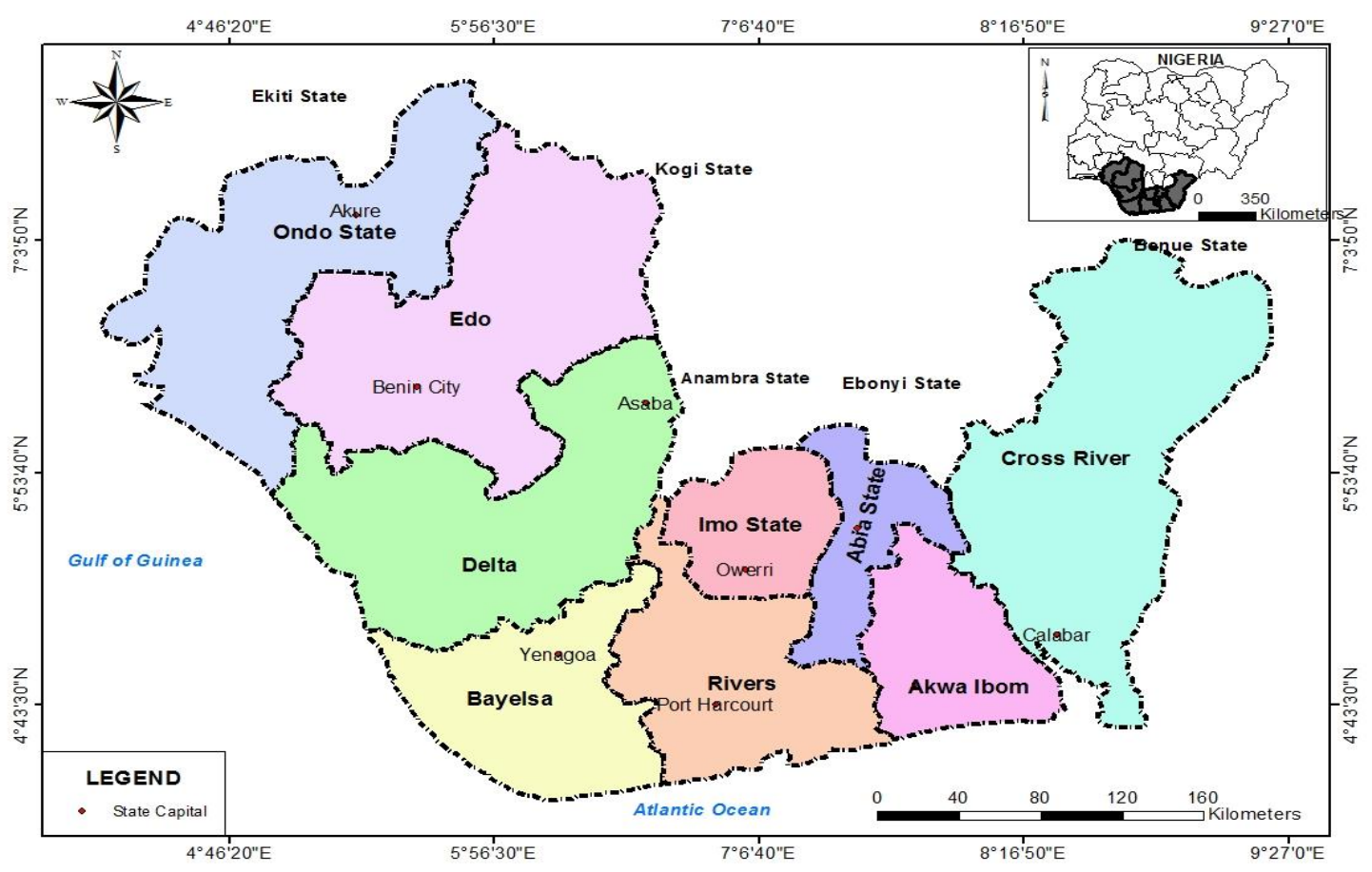

Figure 1. Niger Delta Region

(Source: Cartography and GIS Unit, Dept. of Geography and Env. Mgt. UNIPORT, 2020).

The states domicile in the region include Abia, Akwa- Ibom, Bayelsa, Cross-River, Delta, Edo, Imo, Ondo, and Rivers states. The climate is classed the topical type based on the koppens classification. Rainfall thus ranges from $1950 \mathrm{~mm}$ in the north sections to $2850 \mathrm{~mm}$ in the south and coastal sections of the area. Mean temperature appears to be slightly uniform across the region and ranges 31 degrees in the dry season to 26 degrees in the wet periods. The area was initially agrarian, and it was common to see people engaged in farming or 
animal rearing. More recently, after the discovery of oil and the consequent environmental pollution, the area has become remarkable for environmental pollution and not suitable for agriculture. The ability of the environment to self-regulate is no more possible as spills continue to occur in the area due to vandalism. Albeit, locals continue to fish in the very polluted rivers and consume same fishes and sea foods, thus it is common to see local manifest diseases common with persons that have consumed excess of heavy metals and hydrocarbons (Sanusi et al., 2016).

This study adopted the cross-sectional research design. The target population were locals and MNOC/IOCs. The study used simple random sampling technique. The total population of the area is as presented in table 1. The Taro Yamane equation was used to determine the sample size and 400 respondents were determined for each of the states. This made the total respondents for the locals 1600. On the other hand, 50 MNOC and IOCs staff selected based on staff strength were 50 persons. The total sample size for the study therefore became 1650 , albeit 1560 of the questionnaire administer to the locals were returned.

Table 1. Projected Population of the Study

\begin{tabular}{|l|l|l|l|l|l|}
\hline States & LGAs & Population & $\begin{array}{l}\text { Taro Yamane } \\
\text { Sample Size }\end{array}$ & $\begin{array}{l}\text { Percentage in } \\
\text { Projected Population }\end{array}$ & $\begin{array}{l}\text { Questionnaire Proportion } \\
\text { (Target Population) }\end{array}$ \\
\hline Akwa Ibom & Ibeno & 113,450 & 400 & 54.2 & 217 \\
\hline & Esit Eket & 96,044 & & 45.8 & 183 \\
\hline Total & & 209,494 & & & \\
\hline Rivers & Eleme & 288,315 & 400 & 50.2 & 201 \\
\hline & Ikwerre & 286,399 & & 49.8 & 199 \\
\hline Total & $\begin{array}{l}\text { Isoko } \\
\text { South }\end{array}$ & 574,714 & & & 264 \\
\hline Delta & $\begin{array}{l}\text { Ethiope } \\
\text { East }\end{array}$ & 182,499 & & 66.1 & 136 \\
\hline & & 538,958 & & 33.9 & 119 \\
\hline Total & $\begin{array}{l}\text { Kolokuma/ } \\
\text { Opokuma }\end{array}$ & 120,159 & 400 & 29.8 & 281 \\
\hline Bayelsa & Sagbama & 283,275 & & 70.2 & 1,600 \\
\hline \multicolumn{2}{|l|}{$\begin{array}{l}\text { Total } \\
\text { Respondents) }\end{array}$} & 403,434 & & & 50 \\
\hline $\begin{array}{l}\text { MNOC } \\
\text { Staff }\end{array}$ & & & & & $\mathbf{1 , 6 5 0}$ \\
\hline \multicolumn{2}{|l|}{ Total Respondents } & & & & \\
\hline
\end{tabular}

Source: National Population Commission (2006), Researcher's field work, 2020

The study considered arrays of constructs used in disaster management strategies to arrive at the final output of instrument which was a questionnaire. The reliability of the instrument was achieved using the test re-test method. Two surveys were done in two weeks using $20 \%$ of the sample size (330), on same respondents. After this the Pearson's Product moment correlation was used for the comparisons of both surveys and an $r$ value of 0.91 was realized. The retrieved questionnaire was coded in micro soft excel environment for proper analysis. 


\section{Mll Macrothink}

Weighted mean and percentages were used for validating each construct. Analysis of variance was (ANOVA) was used for testing the hypotheses 'there is no statistical significant spatial difference in level of preparedness for oil and gas pipeline vandalization in the study area' and 'there is no statistical significant spatial variation in the level of disaster mitigation for oil and gas pipeline vandalization in the study area' at the 0.05 level of significance. The analyses were performed in the IBM/SPSS software environment.

\section{Results}

Table 2. Preparedness practices adopted by communities and MNOC/IOCs against pipeline vandalization

\begin{tabular}{|l|l|l|l|l|}
\hline \multirow{2}{*}{ Perceptions } & \multicolumn{2}{l|}{ Communities } & \multicolumn{2}{l|}{ Companies } \\
\cline { 2 - 5 } & Frequency & Percent & Frequency & Percent \\
\hline Hazard, risk and vulnerability assessment & 289 & 18.5 & 38 & 76.0 \\
\hline Response mechanism and strategies & 238 & 15.3 & 4 & 8.0 \\
\hline Coordination of other agencies & 323 & 20.7 & 2 & 4.0 \\
\hline Information management & 201 & 12.9 & 06 & 12 \\
\hline Early warning system & 104 & 6.7 & & \\
\hline Resource mobilization & 139 & 8.9 & & \\
\hline Public education, training and rehearsals & 108 & 6.9 & & \\
\hline None & 158 & 10.1 & & \\
\hline Total & 1560 & 100.0 & 50 & 100.0 \\
\hline
\end{tabular}

Source: Researchers field work (2020)

Table 2, presents preparedness practices adopted by communities and MNOC/IOCs against pipeline vandalization in the selected states. Apparently for the companies four preparedness options are in use and hazard, risk and vulnerability assessment (76\%) is mostly subscribed to by the companies. This means that, the mostly applied preparedness option by the companies may not be effective, as it is at best paper work (Umo-Otong \& Gobo, 2010). Also, looking at the communities, seven preparedness options were purported to be in use, with coordination of other agencies $(20.7 \%)$ being the most identified by the respondents. Sadly, as high as $10.1 \%$ of the respondents adduced that no preparedness whatsoever was unground to handle pipeline vandalism cum disaster when it happens, this finding is consistent with that of Okoli, (2013), Ameh, (2013), Dalby, (2014).

Table 3. The effectiveness of preparedness practice adopted by MNOC/IOCs and communities in the study area

\begin{tabular}{|l|l|l|l|l|}
\hline \multirow{2}{*}{ Perceptions } & \multicolumn{2}{|l|}{ Companies } & \multicolumn{2}{l|}{ Communities } \\
\cline { 2 - 5 } & Frequency & Percent & Frequency & Percent \\
\hline Very Effective & 4 & 8.0 & 258 & 16.5 \\
\hline Effective & 6 & 12.0 & 282 & 18.1 \\
\hline less effective & 38 & 76.0 & 662 & 42.4 \\
\hline Ineffective & 2 & 4.0 & 358 & 22.9 \\
\hline Total & 50 & 100.0 & 1560 & 100.0 \\
\hline
\end{tabular}

Source: Researchers field work (2020) 


\section{Macrothink}

Environmental Management and Sustainable Development

ISSN 2164-7682

2021, Vol. 10, No. 4

The effectiveness of preparedness practice adopted by MNOC/IOCs and communities in the study area is presented in table 3 . the scale for inquiry in the table is designed from very effective to ineffective. In the table most of the respondents identified that preparedness options applied in the area are ineffective whether at the community levels (42\%) or the companies level (76\%). This thus explains the level of pollution that is lucid in the study area as one traverse from the east to the west of the region and has been corroborated by Okon, (2014), and Wizor and Weli, (2020).

Table 4. Mitigation practices against pipeline vandalization adopted by MNOC/IOCs and communities in the study area

\begin{tabular}{|l|l|l|l|l|}
\hline \multirow{2}{*}{ Opinions } & \multicolumn{3}{l|}{ Communities } & \multicolumn{2}{l|}{ Companies } \\
\cline { 2 - 6 } & Frequency & Percent & Frequency & Percent \\
\hline Awareness creation & 432 & 27.7 & 26 & 52 \\
\hline Promoting community participation & 279 & 17.9 & 14 & 28 \\
\hline Community policing & 318 & 20.4 & & \\
\hline Community-based pipeline surveillance & 323 & 20.7 & 10 & 20.0 \\
\hline Community by laws & 62 & 4.0 & & \\
\hline Right of way (ROW) implementation & 113 & 7.2 & & \\
\hline Others (punishment for offenders, excommunication, etc) & 33 & 2.1 & & \\
\hline Total & 1560 & 100.0 & 50 & 100 \\
\hline
\end{tabular}

Source: Researchers field work (2020)

The mitigation practices against pipeline vandalization adopted by MNOC/IOCs and communities in the study area are presented in table 4. The mitigation options therein are awareness creation, promoting community participation, Community policing, community-based pipeline surveillance, community by laws, right of way (ROW) implementation and others (punishment for offenders, excommunication, etc). Awareness creation was the most identified mitigation option by both the community $(27.7 \%)$ or the company $(52 \%)$ respondents.

Table 5. The effectiveness of mitigation options adopted against pipeline vandalization in the study area

\begin{tabular}{|l|l|l|l|l|}
\hline \multirow{2}{*}{ perceptions } & \multicolumn{2}{l|}{ Communities } & \multicolumn{2}{l|}{ Companies } \\
\cline { 2 - 5 } & Frequency & Percent & Frequency & Percent \\
\hline Very Effective & 260 & 16.7 & & \\
\hline Effective & 229 & 14.7 & 8 & 16.0 \\
\hline Less Effective & 749 & 48.0 & 42 & 84.0 \\
\hline Ineffective & 322 & 20.6 & & \\
\hline Total & 1560 & 100.0 & 50 & 100.0 \\
\hline
\end{tabular}

Source: Researchers field work (2020)

The effectiveness of mitigation options adopted by MNOC/IOCs and communities in the study area is presented in table 5. The scale for inquiry in the table is designed from very effective to ineffective. In the table most of the respondents identified that mitigation options 
applied in the area are less effective whether at the community levels (48\%) or the companies level (84\%). This thus explains the level of loss and environmental damage taking place in the study area (Okon, 2014; Wizor \& Wali, 2020).

Table 6. Agencies collaborating with communities and companies on disaster preparedness and mitigation in the study area

\begin{tabular}{|l|l|l|l|l|}
\hline \multirow{2}{*}{ Options } & \multicolumn{2}{l|}{ Communities } & \multicolumn{2}{l|}{ Companies } \\
\cline { 2 - 5 } & Frequency & Percent & Frequency & Percent \\
\hline Federal Government & 295 & 18.9 & 11 & 22.0 \\
\hline MNOC/IOCs & 523 & 33.5 & & \\
\hline NGOs & 162 & 10.4 & 9 & 18.0 \\
\hline National Emergency Management Agency (NEMA) & 244 & 15.6 & 8 & 16.0 \\
\hline National Oil Spill Detection \& Response Agency (NOSDRA) & 234 & 15.0 & 22 & 44.0 \\
\hline Red Cross Society of Nigeria & 102 & 6.5 & & \\
\hline Total & 1560 & 100.0 & 50 & 100.0 \\
\hline
\end{tabular}

Source: Researchers field work (2020)

Table 6 presents the perception of the respondents about the agencies they collaborate with on disaster preparedness and mitigation of oil pipeline vandalism in the study area. Six agencies were identified by the respondents as bodies that collaborate to mitigate oil pipeline vandalism in the study area. For the communities the federal government $(18.9 \%)$ and MNOC/IOCs (33.5\%) were the most cooperating agencies, while red cross $(6.5 \%)$ was the least identified agency by respondents as a body that involves in disaster preparedness and mitigation of oil and gas pipeline vandalism in the study area. As for the companies, the National Oil Spill Detection \& Response Agency (NOSDRA) (44\%), and the federal government (22\%) collaborated more, according to the respondents.

Table 7. Factor affecting the practice of preparedness/ mitigation of effects of oil pipeline vandalization in the study area

\begin{tabular}{|c|c|c|c|c|}
\hline \multirow[t]{2}{*}{ Options } & \multicolumn{2}{|l|}{ Companies } & \multicolumn{2}{|c|}{ Communities } \\
\hline & Frequency & Percent & Frequency & Percent \\
\hline Lack of Commitment from MNOC/IOCs personnel & 12 & 24.0 & 352 & 22.6 \\
\hline Lack of Resources & 6 & 12.0 & 315 & 20.2 \\
\hline Rely on Government & 1 & 2.0 & 384 & 24.6 \\
\hline Rely on Community People & 14 & 28.0 & & \\
\hline Lack of Community Leadership towards Disaster Practice & 9 & 18.0 & 166 & 10.6 \\
\hline None & 6 & 12.0 & 59 & 3.8 \\
\hline Others & 2 & 4.0 & 1 & 0.1 \\
\hline Reliance on oil company & & & 283 & 18.1 \\
\hline Total & 50 & 100.0 & 1560 & 100.0 \\
\hline
\end{tabular}

Source: Researchers field work (2020)

Table 7 presented the factors that affect preparedness and mitigation of effects of oil pipeline vandalization in the study area. The factors listed by respondents in this regard include lack of 
commitment from MNOC/IOCs personnel, lack of resources, reliance on government, reliance on community people, lack of community leadership towards disaster practice, reliance on oil company, none, and other factors (embezzlement of funds, insincerity of leaders, community efforts to thwart government revenue due to poor sharing of resources). However, for the respondents at the companies, lack of commitment from MNOC/IOCs personnel (24\%) and reliance on community people (28\%) were the major factors responsible for poor preparedness and mitigation. For the community respondents, lack of commitment from MNOC/IOCs personnel (22.6\%), lack of resources $(20.2 \%)$ and reliance on government $(24.6 \%)$.

Table 8. Spatial variation in disaster preparedness levels in the study area

\begin{tabular}{|l|l|l|l|l|c|}
\hline \multicolumn{7}{|l|}{ ANOVA } \\
\hline Disaster preparedness levels \\
\hline & Sum of Squares & df & Mean Square & F & Sig. \\
\hline Between Groups & 22.946 & 3 & 7.649 & 14.591 & .000 \\
\hline Within Groups & 815.698 & 1556 & .524 & & \\
\hline Total & 838.644 & 1559 & & & \\
\hline
\end{tabular}

Table 8 presents the spatial variation in pipeline disaster preparedness levels in the selected states where the study was carried out. The model is significant at $\mathrm{p}<0.05(\mathrm{~F}, 14 \mathrm{sig} 0.000)$. This means that the null hypothesis stating there is no statistical significant variation in the level of preparedness for oil and gas pipeline vandalization in the study area is rejected and the alternate hypothesis stating there is, is accepted. This means there is a significant spatial variation in the disaster preparedness measures against oil pipeline vandalism in the area.

Table 9. Duncan statistics showing spatial variation in disaster preparedness measures in the study area

\begin{tabular}{|l|l|l|l|l|}
\hline \multicolumn{5}{|l|}{ Disaster preparedness levels } \\
\hline Duncan $^{\mathrm{a}}$ & \multirow{5}{|l|}{ N } & \multicolumn{3}{l|}{ Subset for alpha $=0.05$} \\
\cline { 3 - 5 } States & & 1 & 2 & 3 \\
\hline Rivers & 390 & 3.0354 & & \\
\hline Bayelsa & 390 & & 3.4030 & \\
\hline Delta & 390 & & & 3.6581 \\
\hline Akwa-Ibom & 390 & & & 3.6703 \\
\hline Sig. & \multicolumn{5}{|l|}{1.000} & 1.000 & .814 \\
\hline Means for groups in homogeneous subsets are displayed. \\
\hline a. Uses Harmonic Mean Sample Size $=390.000$. \\
\hline
\end{tabular}

Table 9, reveals exactly where the difference in disaster preparedness measure lie in the study area. Lucid is that preparedness in Rivers and Bayelsa is below that of Delta and Akwa-Ibom States. In all the preparedness levels are very low across the States. 
Table 10. Spatial variation in pipeline disaster mitigation levels in the study area

\begin{tabular}{|l|l|l|l|l|l|}
\hline \multicolumn{7}{|l|}{ ANOVA } \\
\hline Disaster mitigation preparedness \\
\hline & Sum of Squares & df & Mean Square & F & Sig. \\
\hline Between Groups & 29.927 & 3 & 9.976 & 16.825 & .000 \\
\hline Within Groups & 922.563 & 1556 & .593 & & \\
\hline Total & 952.491 & 1559 & & & \\
\hline
\end{tabular}

Table 10 presents the spatial variation in pipeline disaster mitigation levels in the selected states where the study was carried out. The model is significant at $\mathrm{p}<0.05(\mathrm{~F}, 16.83$, sig 0.000$)$. This means that the null hypothesis stating there is no statistical significant spatial variation in the level of disaster mitigation for oil and gas pipeline vandalization in the study area is rejected and the alternate hypothesis stating there is, is accepted. This means there is a significant spatial variation in the disaster mitigation measures against oil pipeline vandalism in the area.

Table 11. Duncan statistics showing spatial variation in disaster mitigation measures in the study area

\begin{tabular}{|c|c|c|c|}
\hline \multicolumn{4}{|l|}{ Duncan $^{\mathrm{a}}$} \\
\hline \multirow{2}{*}{ States } & \multirow[t]{2}{*}{$\mathrm{N}$} & \multicolumn{2}{|c|}{ Subset for alpha $=0.05$} \\
\hline & & 1 & 2 \\
\hline Rivers & 390 & 3.0142 & \\
\hline Bayelsa & 390 & 3.0202 & \\
\hline Akwa-Ibom & 390 & & 3.5421 \\
\hline Delta & 390 & & 3.6485 \\
\hline Sig. & & 296 & .907 \\
\hline
\end{tabular}

Table 11, reveals exactly where the difference in disaster mitigation measure lie in the study area. Lucid is that mitigation in Rivers and Bayelsa is below that of Delta and Akwa-Ibom States. In all the mitigation levels are very low across the States.

\section{Discussion}

Preparedness practices adopted by communities and MNOC/IOCs against pipeline vandalization in the selected states, shows apparently that of the preparedness options that are in use, hazard, risk and vulnerability assessment is mostly subscribed to by the companies. This means that, the mostly applied preparedness option by the companies is not effective, as it is at best paper work (Umo-Otong \& Gobo, 2010). Also, looking at the communities, seven preparedness options were purported to be in use, with coordination of other agencies being the most identified by the respondents. Sadly, respondents adduced that no preparedness whatsoever was on ground to handle pipeline vandalism cum disaster when it happens, this finding is consistent with that of Okoli, (2013), Ameh, (2013), Dalby, (2014). Meanwhile, Ameh, (2013), asserted that the way the country is handling it oil pipeline installation, 
particularly in the Niger Delta Region, not only put the locals at risk of food insecurity, but also puts plants and animals at the risk of extinction. More so, near nothing is done to mitigate or repel vandal, so that the vandals are having a field day (Wizor \& Wali, 2020). In this study the respondents averred that, the preparedness practice is less effective, confirming the work of Okon, (2014). This thus explains the level of pollution that is lucid in the study area as one traverse from the east to the west of the region and has been corroborated by Okon, (2014), and Wizor and Wali, (2020).

The factors that affect preparedness and mitigation of oil pipeline vandalization in the study area include lack of commitment from MNOC/IOCs personnel, lack of resources, reliance on government, reliance on community people, lack of community leadership towards disaster practice, reliance on oil company, none, and other factors (embezzlement of funds, insincerity of leaders, community efforts to thwart government revenue due to poor sharing of resources). However, for the respondents at the companies, lack of commitment from MNOC/IOCs personnel and reliance on community people were the major factors responsible for poor preparedness and mitigation. For the community respondents, lack of commitment from MNOC/IOCs personnel, lack of resources and reliance on government were the main factors. This finding is in tandem with that of (Tamuno, 2011; Adishi \& Hunga, 2017).

The spatial variation in pipeline disaster preparedness levels in the selected states presented significant model at $\mathrm{p}<0.05(\mathrm{~F}, 14 \mathrm{sig} 0.000)$, implying that there is a significant spatial variation in the disaster preparedness measures against oil pipeline vandalism in the area. Which showed that Rivers and Bayelsa were the least prepared when compared with Delta and Akwa-Ibom States. This finding is corroborated by that of Nwagbosa, (2012), who identified that most of the illegally produced petroleum products emanates from Rivers and Bayelsa states. Sadly, the sources of the crude oil from which the substandard fuel is produced are products of vandalism. According to Ezeoba (2011), the vandals have no regards for the environment and use crude methods in syphoning crude oil and consequently, the rate of pollution in the area is high and devastating for locals who must interact with the environment to survive (Tamuno, 2011; Adishi \& Hunga, 2017).

Similarly, inquiry into the spatial variation in pipeline disaster mitigation levels in the selected states where the study was carried out, showed a significant model at $\mathrm{p}<0.05(\mathrm{~F}$, 16.83, sig 0.000), implying significant spatial variation in the disaster mitigation measures against oil pipeline vandalism in the area. Again, Rivers and Bayelsa were least on the chart in comparison with Delta and Akwa-Ibom States. This finding compares with that of (Duru, 2013).

\section{Conclusion and Recommendation}

The factors that affect preparedness and mitigation against oil pipeline vandalization in the study area included lack of commitment from MNOC/IOCs personnel, lack of resources, reliance on government, reliance on community people, lack of community leadership towards disaster practice, reliance on oil company, other factors (embezzlement of funds, insincerity of leaders, community efforts to thwart government revenue due to poor sharing of resources), adequate re-evaluation of the preparedness and mitigation approaches will in 
no small way improve the environmental health in the study area. Also, Rivers and Bayelsa States ranked lowest in preparedness and mitigation measure as compared to Akwa-Ibom and Delta States. The study thus concludes that more attention be paid to these areas in terms of preparedness and mitigation against oil pipeline vandalism, while not neglecting other areas. In this regard, the following recommendations are advanced:

a) the government, in partnership with the communities should improve on social inclusion and integration of the youth in meaningful employments to reduce the quest for oil theft in the area

b) the government and the MNOCs should improve on the surveillance gargets, so that when pipelines are tampered with, the after effects can be easily mitigated.

c) the place of public orientation and re-orientation cannot be overemphasised. There is therefore, need for government to partner with the communities and MNOCs, to help improve the public perception of government installations in the area, particularly oil and gas pipelines.

d) one of the easiest ways to control crime is to give the youth something to lose. The lip service of government and allied agencies over the years should stop and institutions and companies built in the study area.

\section{References}

Achumba, I. C., Ighomereho, O. S., \& Akpan-Robaro, M. O. M. (2013). Security Challenges in Nigeria and the Implications for Business Activities and Sustainable Development. Journal of Economics and Sustainable Development, 4(2), 79-99.

https://doi.org/10.9774/GLEAF.8757.2013.se.00008

Adekola, J., Fischbacher-Smith, M., Fischbacher-Smith, D., \& Adekola, O. (2016). Health risks from environmental degradation in the Niger Delta, Nigeria. Environment and Planning: Politics and Space, 35(2), 334-354. https://doi.org/10.1177/0263774X16661720

Adekola, O. M., \& Igwe, M. C. (2014). Effects of oil spillage on community development in the Niger Delta Region: Implications for the Eradication of Poverty and Hunger (Millennium Development Goal One) in Nigeria. World Journal of Social Science, 1(1), 27-30. https://doi.org/10.5430/wjss.v1n1p27

Adishi, E., \& Hunga, M. O. (2017). Oil theft, illegal bunkering and pipeline vandalism: its impact on Nigeria economy, 2015-2016. International Journal of Economics and Business Management, 3(2).

Ahmadu, J., \& Egbodion, J. (2013). Effect of oil spillage on cassava production in Niger Delta Region of Nigeria. American Journal of Experimental Agriculture, 3(4), 914-926. https://doi.org/10.9734/AJEA/2013/4374

Aigberua, A. O. (2017). Uncontrolled bush burning in the Niger Delta region of Nigeria: potential causes and impacts on biodiversity. International Journal of Molecular Ecology and Conservation, 7(1), 1-15. 


\section{Macrothink \\ Environmental Management and Sustainable Development \\ ISSN 2164-7682 \\ 2021, Vol. 10, No. 4}

Ameh, J. (2013). Nigeria loses 400,000 barrels of oil daily. The Punch.

Atubi, A. O. (2015). Effects of oil spillage on human health in producing communities of Delta State, Nigeria. European Journal of Business and Social Sciences, 4(8), 14-30.

Dalby, C. (2014). These are the 5 countries most plagued by oil theft. [Online] Available: http://business.financialpost.com/2014/07/04/these-are-the-5-countries-most-plagued-by-oil-t heft/

Daniel, J. K. (2016). Geospatial analysis of encroachments on oil and gas pipeline right-ofway and its effects on the environment along system $2 D$ pipeline, Kaduna state, Nigeria. Unpublished Thesis (Msc.). Ahmadu Bello University, Zaria.

Duru, A. E. (2013). Addressing oil theft, illegal bunkering in Niger Delta. Daily Independent. [Online] Available: http://www.dailindependent.com/2013/11

Nwagboso, C. I. (2012). Security Challenges and Economy of the Nigerian State (2007-2011), American International Journal of Contemporary Research, 2(6), 244-258.

Okoli, A. C., \& Orinya, S. (2013). Oil Pipeline Vandalism and Nigeria's National Security. Global. Journal of Human Social Science Political Science, 13(5).

Okoli, A. C., \& Azom, S. N. (2017). Petro-rentierism, petroleum pipeline vandalism and energy security in Nigeria. Asian International Journal of Social Sciences, 17(2), 41-61. https://doi.org/10.29139/aijss.20170202

Okon, G. B. (2014). The war against oil theft in the Niger delta region and advocacy campaigns by the Nigerian press: a normative appraisal. Studies in Media \& Communication, 2(1), 61-70. https://doi.org/10.11114/smc.v2i1.341

Okonkwo, C. N. P., Kumar, L., \& Tylor, S. (2015). The Niger Delta Wetlands Ecosystems: What threatens it and why should we protect it. African Journal of environmental Science and Technology, 9(5), 451-463. https://doi.org/10.5897/AJEST2014.1841

Salau, S. (2016). Concerns mount over continued attack on oil facilities. The Guardian. p. 28.

Sanusi, A., Onovo, J. C., \& Isa, H. (2016). The Environmental Impact of Pipeline Vandalism. A Challenge to Biodiversity in Port Harcourt Area of Rivers State, Nigeria. International Journal of Advances in Chemical Eng., \& Biological Sciences, 3(1), 142-146.

https://doi.org/10.15242/IJACEBS.A0516206

Wizor, C. H., \& Wali, E. (2020). Crude oil theft in the Niger Delta: the oil companies and host communities' conundrum. International Journal of Research and Scientific Innovation, 7(1), 1-15. 


\section{Macrothink \\ Environmental Management and Sustainable Development \\ ISSN 2164-7682}

\section{Copyright Disclaimer}

Copyright for this article is retained by the author(s), with first publication rights granted to the journal.

This is an open-access article distributed under the terms and conditions of the Creative Commons Attribution license (http://creativecommons.org/licenses/by/4.0/). 